\title{
Variability and diallel analysis of seed protein content in sesame (Sesamum indicum L.)
}

\author{
Aladji abatchoua M.M.I. ${ }^{1 *}$, Dolinassou S. ${ }^{2}$, Nassourou M.A. ${ }^{2}$, Noubissié T.J.B. ${ }^{1}$ and Njintang \\ Y.N. ${ }^{1,3}$ \\ ${ }^{1}$ Department of Biological Sciences, Faculty of Science, University of Ngaoundéré, P.O. Box 454 Ngaoundéré, \\ Cameroon \\ ${ }^{2}$ Department of Biological Sciences, Faculty of Science, University of Maroua, P.O. Box 814 Maroua, \\ Cameroon \\ ${ }^{3}$ Department of Food Sciences, Higher School of Agro-Industrial Science (ENSAI), University of Ngaoundéré, \\ P.O. Box 455 Ngaoundéré, Cameroon
}

*Corresponding Authors: Aladji abatchoua M.M.I, Department of Biological Sciences, Faculty of Science, University of Ngaoundéré, P.O. Box 454 Ngaoundéré, Cameroon

\begin{abstract}
Improvement of seed protein content is one the major objectives in sesame breeding program. The present investigation has been conducted to evaluate the variability of seed protein content in sesame and to investigate their genetic control and combining abilities by using diallel analysis. Twelve genetically diverse sesame pure lines and $15 F_{1}$ hybrids derived from a $6 x 6$ half-diallel crosses mating were sown at Mora (Northern Cameroon) during three cropping seasons in randomized complete block design with three replicates. Significant difference $(p<0.05)$ was observed among the twelve sesame varieties for protein content ranging from 50.75 to $55.23 \%$ DM. Broad sense heritability value was high (0.89), indicating the preponderance of genetic factors controlling this character. Parents and crosses differed significantly for general combining ability (GCA) and specific combining ability (SCA) respectively. The $\delta^{2} G C A / \delta^{2} S C A$ ratio was less than one (0.28) suggesting the preponderance of non-additive genes effects. A parental line with the protein content (L2Y) which was good general combiner exhibited high positive GCA effects indicated that, the parents possess high frequency of favourable genes for proteins. The crosses $L 1 B \times L 2 B, L 1 B \times L 1 Y, L 2 D j x$ $L 1 Y$ and L2Dj $x$ L2Y were found as good specific combining ability. The crosses involving good $x$ good general combiners and showing high SCA effects could be utilized for the purpose of developing high proteins genotypes and obtaining transgressive segregants in early generations.
\end{abstract}

Keywords: Sesamum indicum, half-diallel crosses, genetic improvement, heritability, combining abilities, protein content.

\section{INTRODUCTION}

World's population is increasing day by day at a quite rapid rate and there is a need for staggering increase in food production which is a foremost challenge to feed huge population. Sesame (Sesamum indicum L.) plays an important role in human nutrition. It has been cultivated for centuries, particularly in Asia and Africa because of its high content of edible oil and proteins ${ }^{[1]}$. It is an important source of food and constitutes an inexpensive source of protein (20\%), fat (55\%), minerals and vitamins in the diets of rural populations ${ }^{[2]}$. Fried sesame seed may be mixed with sugar to form a sweet meat or soup ${ }^{[3]}$. The seed of sesame added as ingredients form highly nutritious components of the dessert in cakes and bread ${ }^{[4]}$. They used extensively as a garnish on specially breads, buns and rolls ${ }^{[3]}$. Dehulled sesame seeds are very small, sweet and oleaginous and are used directly for food in the orient ${ }^{[3]}$. The defatted meal prepared from dehulled seeds does not contain undesirable pigments ${ }^{[5]}$. This meal has high potential for use as a protein source or as an ingredient in the food industry ${ }^{[6]}$. Many of the oil-producing plants contain an appreciable level of protein, which has great potential for human diet. White sesame seeds, have higher oil, protein and moisture ratios as compared to black sesame seeds ${ }^{[7]}$. 
Until recently, the improvement of protein quantity in the grains of crop plants has not been a concern of plant breeders in the tropics ${ }^{[8]}$. The direct consumption of vegetable proteins in food products has been increasing over the years because of animal diseases, global shortage of animal protein, strong demand for wholesome and economic reasons ${ }^{[9]}$. Indeed, expeller pressed, dehulled sesame will contain greater than $56 \%$ protein, and dehulled, prepressed and solvent-extracted meal is generally utilized as animal feed and oftentimes as fertilizer ${ }^{[3,10]}$. Even though, considerable attention had been given to the study of sesame seed proteins, there is however very limited information on sesame cultivars grown in Cameroon. In order to improve the efficiency of breeding for sesame proteins, understanding the variation of gene expression of this character is prerequisite. As mentioned previously by ${ }^{[11]}$, sesame possessed a high genetic variability and was predominantly controlled by genetic factors. For there to be success in breeding for increase protein content, it is crucial to identify the parents and crosses that possess genes for high protein content for further genetic improvement [11]. The success of any crop improvement effort depends on potentials inherent in the available genetic materials and the possibility of selection among such potentials. Diallel crosses have been widely utilized in estimating the nature and magnitude of genetic variability of desired trait ${ }^{[12]}$. Further, an understanding of the combining abilities and gene action is the main objective for any successful breeding program ${ }^{[13]}$. The present investigation was undertaken to study the nature of genetic control available for protein and identify suitable parents to be used as donors for increased protein content in sesame.

\section{Materials ANd Methods}

\subsection{Experimental Site}

The study was conducted during three growing seasons in a private farm at Mora, Far North region (Cameroon), which is intersected by $10.32^{\circ} \mathrm{E}$ East longitude and $09.30^{\circ} \mathrm{N}$ North latitude. This region belongs to the sahelian savannah agro-ecological zone. The climate is characterized by two seasons with an average annual rainfall of $1200 \mathrm{~mm}$ that is fairly distributed over the rainy growing period (June to September). The soil of experiments was sandy texture.

\subsection{Plant Material}

Twelve sesame varieties including two lines from Chad: Local 1 Djamena (L1Dj), Local 2 Djamena (L2Dj), two registered genotypes originated from Nigeria: Local 1 Banki (L1B), Local 2 Banki (L2B) and eight local landraces from Northern Cameroon: Local 1 Figuil (L1F), Local 1 Doulo (L1D), Local Podoko (LP), Local Mora (LM), Local 2 Doulo (L2D), Local 2 Figuil (L2F), Local 1 Yagoua (L1Y) and Local 2 Yagoua (L2Y) were used for this research (Table 1). Six genotypes (L1Y, L2Y, L1Dj, L2Dj, L1B and L2B) which were chosen based on their genetic variation for protein content were planted in pots from July to October 2012 for crossings. At flowering, manual crossings were made with emasculation to provide $F_{1}$ generation. At $6 \times 6$ half-diallel mating was obtained giving 21 combinations consisting of six pure lines and $15 \mathrm{~F}_{1}$ hybrids.

\subsection{Experimental Design}

A preliminary field trial was conducted during the first growing season to evaluate the genetic variability for protein content. The seeds of 12 entries were sown in a randomized complete block design (RCBD) with three replications. Sowing took place on an experimental surface of $100 \mathrm{~m}^{2}(20$ $\mathrm{m}$ length $\times 5 \mathrm{~m}$ broad). Each plot unit consisted on one row of $2 \mathrm{~m}$ length $\mathrm{x} 0.5 \mathrm{~m}$ broad, spaced 30 $\mathrm{cm}$ apart. Five seeds of each variety were sown at an intra-row spacing of $30 \mathrm{~cm}$ and thinned to two per hill, 21 days after sowing (DAS). The plots were manually weeded at 20 DAS, 45 DAS and at 65 DAS.

During the next growing season, all 21 genotypes obtained from diallel mating, were arranged in a duplicated randomized complete block design (RCBD) with three replications. Sowing took place on July, 2013, at the beginning of the rainy season on an experiment surface of $300 \mathrm{~m}^{2}(30 \mathrm{~m} \mathrm{x} 10 \mathrm{~m})$. Each plot unit consisted on one row of $2 \mathrm{~m}$ length $\mathrm{x} 0.5 \mathrm{~m}$ broad, spaced $30 \mathrm{~cm}$ apart. Six seeds of each genotype were sown at an intra-row spacing of $30 \mathrm{~cm}$ and thinned to two per hill, 21 days after sowing (DAS). The plots were manually weeded at 20 DAS, 45 DAS and at 65 DAS. At the maturity, the seeds obtained will be harvested and stored. 


\subsection{Determination of Protein Content}

Dried Sesamum indicum L. whole seeds were ground in Moulinex Model SeB PREP'LINE 850. The crude seed protein content of dehulled seeds was estimated by ${ }^{[14]}$ procedures, after extraction of $0.5 \mathrm{~g}$ flour finely crushed defeated oil seed to the SDS $1 \%$ in $0.1 \% \mathrm{NaOH}$ under agitation for $12 \mathrm{~h}$.

\subsection{Statistical and Genetic Analysis}

The data for each combination or those of the local landraces were subjected to analysis of variance (ANOVA) and using STATGRAPHICS PLUS 5.0 statistical package program. The genotypic means were compared using Least Significant Difference at 5\% level of probability (LSD 5\%).

The diallel analysis was done using Dial 98 microcomputer package ascribed by ${ }^{[15]}$. The ${ }^{[13]}$ method 2 (excluding reciprocal $F_{1}$ crosses), model 1 (fixed effects) was used to analyze the general combining ability (GCA) of lines and the specific combining ability (SCA) of crosses, supplemented by the analysis of variance by ${ }^{[16]}$. With this approach, the components of variation were partitioned into the additive effects (a) and the dominance effects (b) which were further sub-divided into $b_{1}, b_{2}$ and $b_{3}$. The genetic parameters were estimated as per ${ }^{[17]}$. Heritability in broad sense $\left(h^{2}\right)$ was measured as the proportion of genetic variance $\left(\delta^{2} \mathrm{~g}\right)$ in the phenotypic variance between the parents $\left(\delta^{2} \mathrm{p}\right)$, while heritability in narrow sense $\left(\mathrm{h}^{2}{ }_{\mathrm{n}}\right)$ was calculated as the proportion of additive variance $\left(\delta^{2} \mathrm{~A}\right)$ in the phenotypic variance between the parents $\left(\delta^{2} \mathrm{p}\right)^{[12]}$. The correlation between parental values $(\operatorname{Pr})$ and recessive factor $(\mathrm{Wr}+\mathrm{Vr})$ indicated the gene action for the trait ${ }^{[13]}$.

\section{RESULTS AND DISCUSSION}

\subsection{Genotypic Variability}

The ANOVA showed a significant differences $(\mathrm{p}<0.05)$ among these twelve promising sesame genotypes (Table 1). For this character, the values of protein percentage in dehulled seeds ranged from $50.75 \%$ to $55.23 \%$ and lines $\mathrm{L} 1 \mathrm{Dj}, \mathrm{L} 1 \mathrm{~F}$ and $\mathrm{L} 1 \mathrm{Y}$ recorded the highest values. Highly significant differences among the genotypes for protein content indicated obviously the substance of a high degree of genetic variation in these materials exploited for the sesame improvement program in Cameroon. ${ }^{[3,6,18,19,20]}$ also reported high genetic variability for protein content. The cultivars, environmental conditions and the extraction method used had an important effect on the highly of proteins obtained ${ }^{[21]}$.

Table 1. Origin and variability of 12 sesame genotypes for dehulled seed protein content

\begin{tabular}{|l|l|l|l|}
\hline Lines & Origin & Seed color & Protein content (\%) \\
\hline L1B & Local 1 Banki (Nigeria) & Black & $53.85 \pm 0.52^{\text {bc }}$ \\
\hline L2B & Local 2 Banki (Nigeria) & White & $50.75 \pm 0.81^{\mathrm{f}}$ \\
\hline L1D & Local 1 Doulo (Cameroon) & Brown & $52.11 \pm 1.07^{\mathrm{de}}$ \\
\hline L2D & Local 2 Doulo (Cameroon) & Brown & $51.21 \pm 0.47^{\text {ef }}$ \\
\hline L1Dj & Local 1 Djamena (Chad) & White & $54.19 \pm 1.40^{\text {ab }}$ \\
\hline L2Dj & Local 2 Djamena (Chad) & White & $52.72 \pm 0.50^{\text {cd }}$ \\
\hline L1F & Local 1 Figuil (Cameroon) & White & $55.23 \pm 0.46^{\text {a }}$ \\
\hline L2F & Local 2 Figuil (Cameroon) & Brown & $53.34 \pm 0.39^{\text {bcd }}$ \\
\hline LM & Local Mora (Cameroon) & Brown & $52.22 \pm 0.83^{\text {de }}$ \\
\hline LP & Local Podoko (Cameroon) & White & $53.04 \pm 0.73^{\text {bcd }}$ \\
\hline L1Y & Local 1 Yagoua (Cameroon) & White & $54.20 \pm 0.53^{\text {ab }}$ \\
\hline L2Y & Local 2 Yagoua (Cameroon) & White & $53.58 \pm 0.45^{\text {bc }}$ \\
\hline Mean & & $53.03 \pm 1.30$ \\
\hline Coefficient of Variation (\%) & 2.45 \\
\hline Least Significant Difference at 5\% level (LSD) & 1.09 \\
\hline
\end{tabular}

Means with the same subscript within the same column do not differ $(p>0.05)$.

\subsection{Diallel Analysis}

The analysis of variance of the mean squares due to the genotypes of general combining ability (GCA), specific combining ability (SCA) (Table 2) showed that, the mean squares of GCA and SCA were both significant $(\mathrm{p}<0.05)$ for this quantitative trait. The ratio between general combining ability and specific combining ability variances for protein content (Table 2) was less than one $\left(\delta^{2} \mathrm{GCA} / \delta^{2} \mathrm{SCA}=0.28\right)$. Diallel analysis based on certain assumptions ${ }^{[12]}$ was fulfilled in present set 
of material where parents were diploid and homozygous pure lines obtained through selfing of several generations. The highly significant difference in mean squares for GCA and SCA implied that there is discernable evidence of inherent genetic variability among the sesame accessions for these characters. Genetic analysis of seed protein content in cotton studied by ${ }^{[22]}$ disclosed that, both GCA and SCA variances were significant in $\mathrm{F}_{1}$. The ratio between general combining ability and specific combining ability was less than one for protein content suggesting that; non-additive gene was predominantly involved in the inheritance of this character; hence, effectiveness of selection in advance generation would be possible. ${ }^{[11]}$ outlined that, proteins was governed by a preponderance of non-additive effects in sesame. ${ }^{[23]}$ and ${ }^{[24]}$ found the involvement of additive and dominance genes in the inheritance of protein in wheat. Cotton seed protein is also predominantly controlled by non-additive gene action ${ }^{[25]}$. In addition, the predominance of non-additive gene action indicated that, this parameter can be enhanced through exploitation of heterosis.

Table 2. Mean squares for general and specific combining ability for sesame in a $6 x 6$ half-diallel crosses of protein content

\begin{tabular}{|l|l|l|}
\hline Source of variation & $\begin{array}{l}\text { Degree of freedom of protein } \\
\text { content }\end{array}$ & Mean squares of protein content \\
\hline GCA & 5 & $6.37^{*}$ \\
\hline SCA & 9 & $5.68^{* *}$ \\
\hline Error & 28 & 1.07 \\
\hline Ratio $\delta^{2} \mathrm{GCA} / \delta^{2} \mathrm{SCA}$ & 0.28 \\
\hline
\end{tabular}

* Significant at 5\%, ** significant at 1\%. GCA: Variation due to general combining ability; SCA: variation due to specific combining ability; Error: error variation or interaction between the replication and genotypes; $\delta^{2} G C A$ : variance of general combining ability; $\delta^{2} S C A$ : variance of specific combining ability.

The mean squares from ${ }^{[16]}$ analysis of variance for additive (a) and dominance (b) effects and dominance components $b_{1}, b_{2}$ and $b_{3}$ for protein content were showed on Table 3 . The analysis showed that, ' $a$ ' and ' $b$ ' items exhibited significant differences among the hybrids and parental lines for this trait. The significant ' $a$ ' and ' $b$ ' items revealed the pronounced contributing of genes showing additive and dominance gene effects. Asymmetry of gene distribution among the parents was indicated by significant ' $b_{2}$ ' item $(p<0.01)$. Significant values of ' $b_{1}$ ' and ' $b_{3}$ ' revealed the presence of unidirectional dominance effects and specific genetic effects respectively. The significance of $b_{1}$ component for protein content indicated that, the dominance was unidirectional. The significant $b_{2}$ item illustrated an asymmetrical distribution of dominant genes among the parents, reflecting that some parents harbored considerably dominant genes than others. Dominant and recessive loci are not harmoniously distributed among the parents. The significance of the residual dominance $\left(b_{3}\right)$ for this characteristic confirmed the presence of specific dominance or combining ability in some crosses.

Table 3. Mean squares from analysis of variance for additive and dominance effects protein content

\begin{tabular}{|l|l|l|}
\hline Source of variation & Degree of freedom & $\begin{array}{l}\text { Mean squares } \\
\text { for protein content }\end{array}$ \\
\hline Replication & 2 & $0.56^{\mathrm{ns}}$ \\
\hline Additive (a) & 5 & $4.86^{* *}$ \\
\hline Dominance (b) & 15 & $11.45^{* *}$ \\
\hline $\mathrm{b}_{1}$ & 1 & $104.84^{* *}$ \\
\hline $\mathrm{b}_{2}$ & 5 & $3.81^{* *}$ \\
\hline $\mathrm{b}_{3}$ & 9 & $5.32^{* *}$ \\
\hline Error & 40 & 0.65 \\
\hline
\end{tabular}

ns: non-significant at 5\% and $* *$ significant at $1 \%, a=$ additive effects of genes; $b=$ dominant effects of genes; $b_{1}=$ mean dominance effects; $b_{2}=$ additional dominance deviation due to the parents, $b_{3}=$ residual dominance effects.

Degree of dominance $\left(\mathrm{H}_{1} / \mathrm{D}\right)^{1 / 2}$ was greater than unity for protein content $(2.84)$ (Table 4$)$. The studied parents possessed high proportion of dominant genes for this trait. The positive estimation of average direction of dominance $(\mathrm{h}=4.75)$ for proteins was recorded (Table 4). Low Narrow sense heritability $\left(h^{2}=0.15\right)$ compared to high broad sense heritability $\left(h^{2}=0.89\right)$ were obtained for this quantitative trait. The regression analysis showed that, the regression coefficient departed significantly from zero for protein content $(0.56)$. The correlation coefficient between $\mathrm{Wr}+\mathrm{Vr}$ and parental means $(\mathrm{r}=-0.97)$ 
was negative but significant for this character. Degree of dominance $\left(\mathrm{H}_{1} / \mathrm{D}\right)^{1 / 2}$ was greater than unity for protein content, thus confirming the presence of over-dominance. The studied parents possessed high proportion of dominant genes for this trait and the direction of dominance gene was positive, suggesting that, dominance gene action played a predominant role in controlling the genetic mechanism of protein content. The significant and negative correlation coefficient between $\mathrm{Wr}+\mathrm{Vr}$ and parental means for protein revealed that, parental lines possessed favorable dominant genes that enhance this character.

Estimates of heritability in broad sense was high indicated that, a large proportion of the total variance was due to the high genotypic variance having less environmental influence. Thus, selection would be effective for these characters. These findings showed that, the smaller values of narrow sense heritability compared to high broad sense heritability suggested that, these traits were mainly controlled by non-additive gene. These results were in agreement with those of ${ }^{[26]}$. As studied previously, ${ }^{[27]}$ obtained high broad sense heritability and low narrow sense heritability for protein content in Vigna unguiculata. In groundnut, moderate broad sense heritability was recorded by ${ }^{[28]}$.

Table4. Genetic components estimates and heritability values for sesame based on a $6 x 6$ half diallel for protein content

\begin{tabular}{|l|l|}
\hline Genetic parameter & $\begin{array}{l}\text { Genetic components estimates } \\
\text { For protein content }\end{array}$ \\
\hline Average degree of dominance $\left(\mathrm{H}_{1} / \mathrm{D}\right)^{1 / 2}$ & 2.84 \\
\hline Proportion of dominant genes $(\mathrm{Kd})$ & 0.57 \\
\hline Direction of dominance $(\mathrm{h})$ & 4.75 \\
\hline Broad sense heritability $\left(\mathrm{h}^{2}\right)$ & 0.89 \\
\hline Narrow sense heritability $\left(\mathrm{h}^{2}\right)$ & 0.15 \\
\hline Regression $(\mathrm{Vr}, \mathrm{Wr})$ & $0.562 \mathrm{Vr}-1.129$ \\
\hline Regression $(\mathrm{Pr}, \mathrm{Wr}+\mathrm{Vr})$ & -0.97 \\
\hline Regression $(\mathrm{Pr}, \mathrm{Wr}+\mathrm{Vr})$ & $-1.91 \mathrm{Pr}+103.63$ \\
\hline
\end{tabular}

$r(P r, W r+V r):$ Correlation coefficient between the degree of dominance of the parents $(W r+V r)$ and the parental value (Pr), Vr: variance of the rth array and Wr: covariance between the parents and their offspring in the rth array.

Combining ability effects for protein content are summarized in Table 5. The results showed that the behavior of the parents varied from one parent from another as well as from the character. A parental line with the protein content (L2Y) which was the best combiner exhibited high positive GCA effects. Nevertheless, sesame lines (L2B, L1Dj and L2Dj) had low and negative GCA effects for this trait. Positive GCA effects exhibited by L1Y genotype could be due to favorable alleles with additive effects for this trait. It was distinguished as a suitable line for being used in sesame hybrid development program, because of desirable GCA for proteins. Significant and positive GCA effects were reported in sesame by ${ }^{[11]}$ for this character. Highly positive significant effect was recorded for GCA for protein contents in Vigna unguiculata by ${ }^{[27]}$; in Triticum aestivum by ${ }^{[29]}$ and in Oryza sativa by ${ }^{[30]}$.

Table 5. Estimates of general combining ability (GCA) effects for protein content

\begin{tabular}{|l|l|}
\hline Parents & General combining ability effects \\
\hline Local 1 Banki (L1B) & 0.01 \\
\hline Local 2Banki (L2B) & $-0.23^{*}$ \\
\hline Local 1 Djamena (L1Dj) & $-0.3^{*}$ \\
\hline Local 2 Djamena (L2Dj) & $-0.90^{*}$ \\
\hline Local 1 Yagoua (L1Y) & 0.14 \\
\hline Local 2 Yagoua (L2Y) & $1.30^{* *}$ \\
\hline Standard Error (SE) & 0.66 \\
\hline
\end{tabular}

* Significant at $5 \%$ and $* *$ Significant at $1 \%$.

Estimates of specific combining ability (SCA) effects for protein content evaluated in the fifteen crosses are presented in Table 6. Globally, significant positive SCA effects were obtained in some crosses. The combinations L1B x L2B, L1B x L1Y, L2Dj x L1Y and L2Dj x L2Y were involved more frequently in the crosses exhibiting significant positive SCA effects for this trait. Crosses showed superior SCA effect suggested the complementary between sesame lines used in these 
crosses. Therefore, these hybrids and their parents may further utilize in future breeding program of promising high-protein genotypes development. These findings were in agreement with results obtained by ${ }^{[11]}{ }^{[31]}$ and ${ }^{[32]}$ showing significant positive SCA effects for protein content respectively in Helianthus annuus and in Zea mays.

Table6. Estimates of specific combining ability (SCA) effects among $15 F_{1}$ hybrids for protein content

\begin{tabular}{|l|l|}
\hline Crosses & Specific combining ability effects \\
\hline L1B x L2B & $0.88^{* *}$ \\
\hline L1B x L1Dj & $-0.72^{*}$ \\
\hline L1B x L2Dj & $-1.97^{*}$ \\
\hline L1B x L1Y & $1.41^{* *}$ \\
\hline L1B x L2Y & $0.40^{*}$ \\
\hline L2B x L1Dj & $-0.66^{*}$ \\
\hline L2B x L2Dj & $-0.53^{*}$ \\
\hline L2B x L1Y & $-0.12^{*}$ \\
\hline L2B x L2 Y & $0.42^{*}$ \\
\hline L1Dj x L2Dj & $0.51^{*}$ \\
\hline L1Dj x L1Y & $0.41^{*}$ \\
\hline L1Dj x L2Y & $0.45^{*}$ \\
\hline L2Dj x L1Y & $0.78^{* *}$ \\
\hline L2Dj x L2Y & $1.21^{* *}$ \\
\hline L1Y x L2Y & -2.48 \\
\hline Standard Error (SE) & 0.32 \\
\hline
\end{tabular}

* Significant at $5 \%$ and $* *$ Significant at $1 \%$.

The $\mathrm{Wr} / \mathrm{Vr}$ graphs (Figure 1) showed that, the scatter points were within the limiting parabola in protein content. The $\mathrm{Wr} / \mathrm{Vr}$ graphs revealed also that, the regression line $(\mathrm{Wr}=0.562 \mathrm{Vr}-1.129)$ passed the $\mathrm{Wr}$ axis much below the origin. The regression coefficient of $\mathrm{Wr}$ on $\mathrm{Vr}$ for this character $(0.56)$ differed significantly from zero. The distribution of array points along the regression line showing some varieties were nearest to the origin while others were furthest away from the origin. By viewing the $\mathrm{Wr} / \mathrm{Vr}$ graphical description for the protein content, it is clear that the intercept of the regression line on the covariance axis is on the negative side i.e. below the point of origin indicates the involvement of over-dominance type of gene action. As the regression coefficient did not differ significantly from unity, hence the non-allelic interactions were absent, thus the additive-dominance model was adequate for seed protein content. The scattered array varietal points along the regression line showed that maximum dominant genes were observed in L2B as nearer to the point of origin and L1Dj, L1Y and L2Y receives maximum recessive genes being distant from the origin. Prevalence of over dominance type of gene action indicated that, fruitful selection in early generations is not possible and it must delay till later generations. In Triticum aestivum, the genetic analysis suggested that the grain protein could be improved through pedigree and progeny selection ${ }^{[29]}$. In biotechnological features of sesame seed protein, genetic mapping provides an essential tool to understand the genetic architecture of this quantitative trait at molecular level.

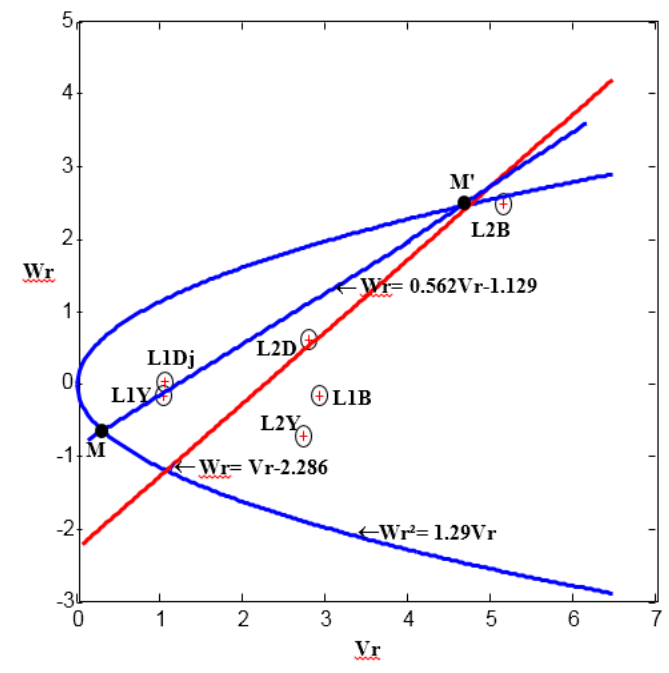

Figure1. $\mathrm{Wr} / \mathrm{Vr}$ graph for protein content 
$W r^{2}=V r V p$ : Limiting parabola where $V p$ is the variance of the parents; Vr the variance of the rth array and Wr is the covariance between the parents and their offspring in the rth array. Solid line: tangent to the limiting parabola $(W r=1 V r+b)$; dotted line: regression of Wr on Vr. L1Y: Local 1 Yagoua, L2Y: Local 2 Yagoua, L1Dj: Local 1 Djamena, L2Dj: Local 2 Djamena, L1B: Local 1 Banki and L2B: Local 2 Banki.

\section{CONCLUSION}

From the present research, studied parents showed highly significant differences for seed protein content. Dominant alleles tend to increase seed protein content. It is suggested that due to more prominent role of non-additive gene effects and presence of over-dominance type of gene action, selection for improving this trait could be delayed up to late segregating generations. The present study can therefore be employed in the selection of genotypes from various sources to form a wide gene pool with broad genetic base on which future breeding program could be hinged. For future researches, identification and monitoring of quantitative trait loci could be better for increased protein content in succeeding segregating populations.

\section{ACKNOWLEDGEMENT}

Authors are thankful to Prof UKAI YASUO of the University of Tokyo for providing the DIAL computer program used to carry out the present work.

\section{REFERENCES}

[1] Johnson L.A., Suleiman T.M., Lusas E.W., Sesame protein: A review and prospectus. J. Amer. Oil Chem. Soc. (1979), 56: 463-468.

[2] Jeong S.M., Kim S.Y., Kim D.R., Nam K.C., Ahn D.U., Lee C., Effect of seed roasting conditions on the antioxidant activity of defatted sesame meal extracts. J. Food Sci. (2004), 69(5), 377-381.

[3] Ranganayaki S., Vidhya R., Jaganmohan R., Isolation and proximate determination of protein using defatted sesame seed oil cake. Int. J. Nutr. Metab. (2012), 4(10), 141-145.

[4] Iman T., Leila P., Mohammad R.B., Sadolla M., Mokhtar J.J., Ülo N., Genetic variation among Iranian sesame (Sesamum indicum L.) accessions vis-à-vis exotic genotypes on the basis of morpho-physiological traits and RAPD markers, Austr. J. Crop Sci. (2011), 5(11), 1396-1407.

[5] Daghir N.J., Ullah M.F., Rotterstenk L., Lysine supplement of sesame meal, Trop. Agric. (1967), 44: 235245.

[6] Onsaard E., Pomsamud P., Audtum P., Functional properties of sesame protein concentrates from sesame meal. Asian J. Food Agro-Ind. (2010), 3(4), 420-431.

[7] Kanu P.J., Biochemical analysis of black and white sesame seeds from China. Amer. J. Biochem. Mol Biol. (2011), 1: 145-157.

[8] Ramalho M.A., Andrade de Araujo L.C., Breeding self-pollinated plants. Crop Breed. Applied Biotechnol. (2011), S1: 1-7.

[9] Asgar M.A., Fazilah A., Huda N., Bhat R., Karim A.A., Nonmeat protein alternatives as meat extenders and meat analogs, Comprehensive Reviews in Food Science and Food Safety (2010), 9: 513-529.

[10] Inyang U.E., Iduh A.O., Influence of $\mathrm{pH}$ and salt concentration on protein solubility, emulsifying and foaming properties of sesame protein concentrate. J. Amer. Oil Chem. Soc. (1996), 73(12), 1663-1667.

[11] Azeez M.A., Morakinyo J.A., Combining ability studies and potential for oil quality improvement in sesame (Sesamum indicum L.). J. Agroaliment. Proc. Technol. (2014), 20(1), 1-8.

[12] Mather K., Jinks J.L., Biometrical genetics, Chapman and Hall. $2^{\text {nd }}$ edition, London U.K. (1982), pp 179282.

[13] Griffing B., A generalized treatment of the use of diallel crosses in quantitative inheritance. Heredity (1956), 30: 31-51.

[14] Lowry O.H., Rosebrough N.J., Farr A.L., Randall R.J., Protein measurement with folin-phenol reagent. J. Biol. Chem. (1951), 5: 193-265.

[15] Ukai Y., DIAL, programs for the analysis of full or half diallel table, University of Tokyo, Japan, pp 18, (2002). http: //plach.ab.a.u-tokyo ac.jp.

[16] Walters D.E., Morton J.R., On the analysis of variance of a half diallel table. Biometrics (1978), 34: 91-94.

[17] Hayman B., The theory and analysis of diallel crosses, Genetics (1954), 39: 789-809.

[18] Gandhi A.P., Srivastava J., Studies on the production of protein isolates from defatted sesame seed (Sesamum indicum) flour and their nutritional profile. Asean Food J. (2007), 14(3), 175-180.

[19] Vijayakuamar P.T., Bukya A., Properties of industrial fractions of sesame seed (Sesamum indicum L.). Int. J. Agric. Food Sci. (2013), 3(3), 86-89. 
[20] Hafida H., Meriem El-H., Abdelghani N., Hajar R., Hassan L., Said E., Biochemical assessment of the genetic diversity among thirteen Moroccan genotypes of sesame (Sesamum indicum). Int. J. Develop. Res. (2015), 5(4): 4010-4020.

[21] Vasconcelos I.M., Maia F.M.M., Farias D.F., Campello C.C., Carvalho A.F.O., Moreira R.A., Abreu de Oliveira J.T., Protein fractions, amino acid composition and antinutritional constituents of high-yielding cowpea cultivars. J. Food Compos. Anal. (2010), 23: 54-60.

[22] Padimi S., Singh H.G., Genetic analysis of protein content in cotton seed. Indian J. Genet. (1985), 45(2), 385-388.

[23] Rathod S.S.K., Dobariya L., Jivani L.L., Ponkia H.P., Analysis for test weight, protein content and grain yield in six crosses of bread wheat (Triticum aestivum L.). Adv. Plant Sci. (2008), 21(1), 99-101.

[24] Singh K., Gupta P.K., Tewari N., Combining ability analysis for yield and quality traits in spring wheat (Triticum aestivum Linn. Emend Thell). Progressive Agric. (2009), 9(2), 235-241.

[25] Ashokkumar K., Ravikesavan R., Conventional and molecular breeding approaches for seed oil and seed protein content improvement in cotton. Int. Res. J. Plant Sci. (2011), 2(2): 37-45.

[26] Sandipan C., Animesh K.D., Aditi S., Sonali S., Rita P., Susmita M, Ananya D., Traits influencing yield in sesame (Sesamum indicum L.) and multilocational trials of yield parameters in some desirable plant types. Indian J. Sci. Technol. (2010), 3(2), 163-166.

[27] Noubissié T.J.B., Bell J.M., Nassourou A.M., Njintang N.Y., Youmbi E., Genetic analysis of seed proteins contents in cowpea (Vigna unguiculata L. Walp). Afr. J. Biotechnol. (2011), 10(16), 3077-3086.

[28] Noubissié T.J.B., Njintang N.Y., Dolinassou S., Heritability of proteins and oil contents in groundnut (Arachis hypogea L.) genotypes. Int. J. In. Bio-sci. (2012), 2(3): 162-171.

[29] Yao J., Hongxiang M.A., Yang X., Zhou M., Yang D., Genetic analysis of the grain protein content in soft red winter wheat (Triticum aestivum L.). Turkish J. Field Crops (2014), 19(2), 246-251.

[30] Anyanwu P.C., Ubi U.I., Heterosis and combining ability effect of protein content on rice (Oryza sativa L.) genotypes. J. Plant Breed. Crop Sci. (2015), 7(8), 256-261.

[31] Nasreen S., Ishaque M., Khan M.A., Saleem-ud-din, Syeda M.G., Combining ability analysis for seed proteins, oil content and fatty acids composition in sunflower (Helianthus annuus L.). Pakistan J. Agric. Res. (2014), 27(3), 174-187.

[32] Singh A.K., Singh P.K., Ranjan R., Shahi J.P., Studies on combining ability analysis in white kernel colour of quality protein maize (Zea mays L.). Agric. Sci. Digest. (2014), 34(1), 21-25.

Citation: Aladji abatchoua M.M.I., et.al.,, "Variability and diallel analysis of seed protein content in sesame (Sesamum indicum L.)." International Journal of Research Studies in Agricultural Sciences (IJRSAS), 2020; 6(10), pp. 1-8, https://doi.org/10.20431/2454-6224.0610001

Copyright: () 2020 Authors. This is an open-access article distributed under the terms of the Creative Commons Attribution License, which permits unrestricted use, distribution, and reproduction in any medium, provided the original author and source are credited. 